\title{
15. How Relevant are European Models of Government to Pacific Island States?
}

\author{
Jon Fraenkel
}

Les modèles européens de gouvernance sont-ils pertinents pour les Etats du Pacifique insulaire?

Dans tout le Pacifique insulaire, des modèles de gouvernance originaires d'autres parties du monde sont souvent présentés comme des solutions aux problèmes locaux, que la situation problématique soit réelle ou simplement perçue comme telle. Cependant, les enjeux autour de la construction de l'Etat ou de la nation ne sont plus, au 2le siècle, les mêmes que ceux posés aux 19e et 20e siècles. Si les modèles européens eurent une grande influence durant l'époque coloniale, leur héritage post-colonial fut mitigé: l'influence continua d'être forte pour le législatif et la gouvernance, mais la variation dans les adaptations fut plus grande que ce qu'on imagine souvent. Maintenant que les Etats insulaires abordent leur troisième, quatrième ou parfois cinquième décennie dans leur indépendance, l'influence des modèles européens s'est encore dissipée davantage, et de nouvelles influences sont apparues. Des modèles de gouvernance venus d'ailleurs et des institutions importées-quand les circonstances sont inhabituelles-- ont joué un rôle significatif et positif, parfois de manière imprévue. Mais ceux qui appellent à ces changements feraient bien de ne pas se cantonner à de grands principes internationaux et devraient plutôt ancrer leurs arguments dans une prise en compte du contexte local, de façon détaillée et en profondeur.

Around the Pacific Islands region, one often hears models of government from elsewhere extolled as solutions to various perceived or real political problems. Models of institutions back home are frequently carried around in the back of the heads of diplomats, seconded advisors and well-paid consultants from overseas and depicted as solutions to every political difficulty in the Pacific.

I was at a workshop organised by Papua New Guinea's Commission on the Integrity of Political Parties and Candidates a few weeks ago in Gaire, outside Port Moresby. This was aimed at discussing feasible alternatives in the wake of a July 2010 decision ruling unconstitutional a law aimed at tying MPs to particular Prime Ministers and lessening the incidence of 'no confidence' motions. As those of you who know the country well will be aware, the parliament has 
been plagued by incessant 'no confidence' votes, long adjournments to avoid challenges to incumbent governments and usages of cash and ministerial portfolio handouts to hold together fragile coalitions. At that meeting, a UNDP representative insisted that a European (or Latin American)-style list proportional representation system would resolve all these difficulties of party loyalty, despite much contrary evidence. Despite the efforts of many with years of experience in the many twists and turns of Papua New Guinea politics, no one could convince her that these problems would not be resolved simply by tweaking the electoral rules.

It is an all-too frequent kind of error: both in analysis and recommendation. One often hears Pacific chiefly systems described as 'feudal' drawing on the European historical experience, for example, without much attention to studying forms of tribute or labour service if these exist at all (and they usually don't). At embassy or high commission garden parties, you regularly hear European, Australian or American history drawn upon to explain how islands should travel on the rocky road towards democracy. Interesting - perhaps sometimes, but usually misleading as regards the kind of issues faced by small island polities in the $21 \mathrm{st}$ century.

This is certainly not an exclusively European penchant. More unofficially than officially, Australians in the Pacific regularly emphasise the virtues of preferential voting systems (as used both for federal and state level governments), and that regional influence has obviously been important in the adoption of such systems both in Fiji and Papua New Guinea. A few years ago, as Fiji wrestled with the problems of handling mandatory power-sharing between highly polarised political adversaries, I recall New Zealand advisors emphasising their own unique qualifications in handling coalition governments (heedless of the massive differences between voluntary and mandatory power-sharing).

On Europe day over the last decade around the islands, diplomats frequently point to the Treaty of Rome and the European Union as a viable model for Pacific regionalism. Yet the "German question" that loomed so large in late 19th and early 20th century European history, and so influenced the initial steps towards European unification, has no meaningful or likely parallel in the Pacific Islands. The Pacific Islands are, for the most part, separated by vast sea areas, and do not have a history of states forged through warfare that closely resembles the European experience. The recent spat between Tonga and Fiji over the Minerva Reef hardly resembles the controversies over Alsace-Lorraine in the 1870s or the 1937-8 German Sudetenland. The gains from trade and capital flows witnessed by a Europe without borders are scarcely likely to be replicated in Oceania, where island countries have little to trade with each other and little capital to export. 
If European regionalism provides an intriguing model of government, it would surely rather be inclusive of Australia and New Zealand, which dominate so much of the trade at least to the South Pacific island countries. For here one might consider how European regionalism tied together stronger and weaker economies: Germany and northern Europe together with historically weaker economies like Ireland, Portugal and parts of the Southern Mediterranean. The cost of such arrangements, including permitting access for labour to Australasia, would probably be far less than that incurred by the stronger economies of northern Europe. After all, there is little likelihood that a bankrupt Tonga or Tuvalu (should that arise) will put as much pressure on the vitality of the financial system as Greece, Ireland or Portugal do on that of contemporary Europe.

Warning against unthinking transplantations, of course, is not an argument against all comparisons, or useful lessons drawn from different parts of the world. It is only to counsel against poorly thought-through recommendations, disregarding the vast differences between European, North American and Pacific settings. Even within the region, partly due to the experience of Christianisation, there is often a perception that Pacific peoples are fated to tread a similar path to Europeans, North Americans or Australasians. Amongst Europeans deployed on brief employment contracts in the Pacific Islands, there is an understandable urge to reach for the familiar, the known and the proven workable.

In universities, also, states in other parts of the world are often understood through the European lens, or measured by their correspondence to European perceptions of what constitutes an effective or viable state. They are defined as something other than European states. They are not Westphalian states. They are not Max Weber's 'rational-legal bureaucratic' states. They are not states like those European institutions splendidly studied by Charles Tilly (1990), where war built revenues and peace built institutions of accountability and democracy, though such tax-raising states regularly figure in the donor literature as a suitable model for elsewhere. Jeffrey Herbst's excellent study of the way the African experience of warfare and state-building differs from that in Europe provides a useful example of the kind of theorising about the state that might be attempted for the Pacific Islands (Herbst 2000).

Perhaps one way to address the question of the relevance of European models of governance in the present or future tense is to first consider their relevance in the past. In this paper, I focus mainly on the South Pacific, where the principle colonial influences were European, or by extension, Australasian, whereas in the northern Pacific the key influences (eventually) became American.

European models of government have influenced the past and still influence the present of many Pacific Island states. Most obviously, the French territories 
of New Caledonia, French Polynesia and Wallis and Futuna not only have Francophone systems of law, but still participate in elections to the National Assembly in Paris and for the French President. In some cases, departures from French influences have proved critical for political settlements. For example, New Caledonia's Noumea Accord entailed such a breach with French legal doctrine that it required a constitutional amendment and a referendum in France.

While the former British territories are all de-colonised (bar tiny Pitcairn Island), the English system of common law remains in operation in varying ways in the former colonies. Westminster systems were left in both in former British territories, and in countries where the colonial power had been Australia or New Zealand - although often with more consultation about the shape of post-colonial arrangements than is commonly recognised by those who critique the 'imposition' of Westminster on island territories. In Solomon Islands, for example, the British experimented with a 'Governing Council' system alleged to be more suitable for a 'Melanesian' context, but it was ambitious politician Solomon Mamaloni that urged adoption of a full-scale Westminster system with a 'Prime Minister' and 'cabinet', a Leader of the Opposition and, curiously, even a 'leader' of the independent members of parliament. In Papua New Guinea and Kiribati too, there was more local-level discussion about the modification of inherited institutions than is commonly realised. Too much is often blamed on the 'Westminster' legacy by Pacific commentators, partly due to rosy-eyed claims about a propensity to consensus inherent in Pacific cultures.

In the New Hebrides (Vanuatu), the electoral system adopted at independence - the single non-transferable vote - was a compromise between the British and French authorities designed to ensure that the Anglophone majority did not win all the seats in parliament. That system exists nowhere in Europe, but today only for the lower house in Afghanistan (having been dropped in Japan, Taiwan, South Korea and, recently, Jordan). The electoral system of Nauru also has no parallels to anything currently in use in Europe, but resembles the system invented by French 19th century mathematician Jean Charles De Borda. It is a preferential system, but with a second preference counted as worth 0.5 , a third as 0.33 and so on, and all preferences immediately tallied to get a result. Known in Nauru as the Dowdell system, it is in fact named after the Irishman in government at independence who devised it. In Kiribati (the former British Gilbert Islands), a unique presidential system was adopted at independence that bears no resemblance to anything elsewhere in the world (let alone Europe). The President is directly elected, but constrained to form a cabinet from within parliament. The nominees for a presidential election are decided by parliament, and, particularly unusually, the President can be ousted by a parliamentary 'no confidence' vote, but in such cases there is an immediate dissolution of parliament. Designed to ensure presidential support in parliament, the system 
has worked reasonably well since independence (as compared to neighbouring Tuvalu and Nauru, which have both experienced numerous no confidence votes and regular changes of government).

Going back further, the Pacific Islands can count some very odd experiences with European models of government. It was Pope Leo XIII in Rome who was called upon to deliberate on the division of Micronesia in 1885 between Spain and Germany. Tonga's monarchy has commonly been described as an 'absolutist' system typifying an extremely hierarchical variant of the Polynesian chiefly system. In fact, it was an adaptation to European styles of monarchic rule codified in the 1875 constitution in an effort to resist the influence of European colonisers. Samoa found itself under a tripartite 'condominium' or 'Tridominium' in 1889, run together by the United States, Germany and Britain, but with key appointments made, rather bizarrely, by the King of Sweden. The New Hebrides (Vanuatu) also found itself with a European 'Condominium' (agreed as part of the Anglo-French entente cordiale in 1906) - an arrangement much later famously described rather as rather more 'pandemonium' than 'condominium' by Vanuatu's first post-independence Prime Minister Walter Lini.

Of course, the models of government suitable for Pacific colonists were not at all those favoured, or conceded, back at home. Usually, there was initially no elected representation. In Fiji, for example, for the first 25 years of colonial rule Governor Sir Arthur Gordon and his successors ran the show, though with a native administration - a state within a state - sometimes described as a precursor to Lord Lugard's 'indirect rule' arrangements in Nigeria. Only in the early years of the 20th century were local Europeans and Fijians granted nominees on the Legislative Council. Only in 1929 were the descendants of Indian indentured labourers granted elected representation, and then only on communal rolls regarded as symptomatic of colonial oppression by Mahatma Ghandi and many amongst the Fiji Indian leaders. Ethnic Fijians did not get the vote until 1963, and by then stark divisions as regards what could be expected from constitutional democracy were well-ingrained. In Solomon Islands, it was only after the Maasina Ruru uprising of the 1940s that the British colonists experimented with local-level governments. It was in the French territories - New Caledonia and French Polynesia - that extension of the franchise and territorial assembles emerged first, and with these political parties. In the British territories, democracy - after a fashion - emerged only very late in the colonial era, and even then at first under a continuing official majority.

That said, the forms of colonial rule witnessed in the Pacific Islands, if we exclude the early Spanish adventures, were very different to those that would have been experienced if the Pacific had been carved up in the 17th or 18th centuries. By the second half of the 19th century, colonial adventures were characterised by what Jane Samson (1998) calls 'imperial benevolence'. Fiji's colonisation in 1874 
was partly triggered by the activities of unruly white settlers in Levuka, and also by the desire to control the trade in indentured labourers that had reached the New Hebrides, Solomon Islands and even island New Guinea. Oddly, both British rule in Fiji and German rule in Samoa entailed a 'protectionist' apparatus that restricted employment on plantations and sought to control, minimise or abolish alienation of native lands. Tonga's monarchic system survived despite a very loose form of colonial control, while the monarchies in Hawaii and Tahiti (if monarchy that can be called) were abolished - the former as a result of the Pacific's first coup d'êtat by American settlers in 1893. In most of the British territories, the most cost-effective forms of colonial government were thought to allow the continuation of local forms of government (where possible), even if - to raise money - much de facto control was conceded to big companies like the CSR, Lever Brothers, Carpenters, and Burns Philp among others.

For much of the Pacific, the colonial influence remained small for the first half century or so. The location of colonial capitals on small offshore islands, like Tulagi in Solomon Islands, Jaluit in the German Marshall Islands or Ovalau (Levuka) in Fiji was testimony to restricted influence on the larger and more populous islands. There was a problem of control. Most Pacific islanders, particularly in Melanesia, continued to reside in rural areas with little or no contact with threadbare colonial administrations, which were required to finance their own operations (there was usually no 'aid' and where there were loans these had to be raised on the private money markets). The Edwardian era was a brief golden age for the colonial plantation economies, boosted by rising world prices and still favourable possibilities for importing indentured labour from India, China or Java, but by 1914 the world was plunged into a new era of economic uncertainty. Indentured labourers were no longer recruited from India for Fiji after 1916, and the troubled recruitment of Chinese for Samoan plantations had also halted. The global depression in commodity prices of the 1920s was reinforced by a broader collapse in the World economy during 1929-32, although the forms of protection adopted in response paradoxically assisted Fiji's sugar industry while the approach of war fuelled demand for New Caledonian nickel.

The Pacific War, when it came, was not only a final nail in the coffin of the European-owned plantation system, but also damaged the political authority of European colonialism. Americans in unprecedented numbers - far greater than the pre-war number of European colonists - spread across that thick Oceanic line of resistance to the Japanese advance connecting Hawaii to Australia. They paid higher wages, and brought numerous new influences. With the end of that war, forms of quasi-'colonial' rule also changed, with the advent of United Nations Trust territories in Micronesia (and building on the earlier arrangements under 
the League of Nations for Western Samoa, Nauru and New Guinea). That notion of trusteeship, and administration oriented towards development and eventual independence, further undermined the moral certainties of the colonial era.

Western Samoa was the first to de-colonise in 1962, and when it did so it adopted arrangements very different to those of its 'trustee' power, New Zealand. Only matai (chiefs or family heads) could vote or stand for parliament, an arrangement much criticised by some, but recognised by a visiting U.N. team as 'democracy in two stages', i.e., accommodating traditional methods of leadership selection through the matai-only franchise. That arrangement was partially changed in 1991, when the franchise was opened to all citizens, although it remains the case that candidates must be matai. Those who criticise that system as 'undemocratic' are often unaware that there were already 35,000 matai titles in the early 1990s (according to the records at the Land and Titles office), and there will be many more now. Far from being a tradition-bound government, Samoa is probably one of the most reform-oriented countries in the world - few states could change what side of the road their cars drive on and shift the dateline eastwards so as to enter the same time-zone as its major trading partners. By most measures, Samoa probably has the most robust of the island governments - with a single party in office for nearly 30 years (with one brief exception) and is carefully (and healthily) resistant to the imposition of outside models.

For Fiji, which became independent in 1970, the new arrangements bore the colonial imprint. There was a British-style Westminster parliamentary system, together with an upper house (called the Senate) and a first-past-the-post electoral system, but there were also communal electoral rolls that separated 'Fijians', 'Indians' and 'general' voters, and the Great Council of Chiefs played an important role with regard to Senate selection. The dangers inherent in that deeply divided polity, and in those choices of institutional arrangements, were already evident before independence, and were highlighted again by the Street Commission report of 1975, which recommended the abolition of communal rolls and introduction of a system of proportional representation. A constitutional crisis in April 1977, and coups in 1987 and 2000, in each case followed the election of governments largely drawing on the votes of the Fiji Indian population (slightly larger than the indigenous Fijian population from 1944-1987). The extraordinary political settlement reached in 1997 between ethnic Fijian and Fiji Indian political leaders did not survive the pressures generated by the first election under the new arrangements in 1999 (when the country elected its first ever Prime Minister of Indian descent, Mahendra Chaudhry). The coup of 2000 unleashed a new set of destabilising forces, with the military seizing power yet again in December 2006 but this time promising a 'coup to end all coups' in the name of multi-racialism, good governance and anti-corruption. Four and a half years later, military rule remains in place, but the promises of 2006-7 have been thoroughly breached. 
None of the other Pacific countries was faced with the problem of designing political institutions capable of withstanding deep bipolar divisions like those in Fiji with the partial exception of New Caledonia. There the division between pro- and anti-independentists brought the territory to the brink of civil warfare in the mid-1980s, although ethnicity was never as coterminous with political party affiliation in the way that it was in Fiji. The 1988 Matignon and 1998 Noumea Accords, agreed between leaders of the largely Kanak-backed FLNKS and the largely (but not exclusively) settler backed RPCR entailed in the latter case (i) regional autonomy, (ii) power-sharing (or 'collegial') cabinet and (iii) an agreement to put off the vote on independence until 2014-19. As previously mentioned, much about the Noumea Accord entailed a departure from constitutional arrangements long deemed sacrosanct in France. As the deadline approaches, many are fearful of resorting to a polarising vote on independence. Others are canvassing further shifts in once unshakeable Gaullist doctrines for the French overseas territories, and considering the possibility of 'free association' arrangements such as those between New Zealand and Niue and the Cook Islands, or between the USA and the Republic of the Marshall Islands, Federated States of Micronesia and Palau.

Resolving secessionist disputes by agreement on a delayed vote on independence was also a critical element of the arrangements reached to bring to an end a decade of low intensity civil warfare on the island of Bougainville. [The only other country in the world to have agreed such arrangements is Sudan, now about to reach the point of separation]. In Bougainville, now an autonomous region of Papua New Guinea, a unique presidential system was adopted, with many constraints on cabinet formation designed to accommodate the demands of women, former militants and the different regions. A vote on independence is due between 2015-20, but with nothing resembling the buckets of French aid that have poured into largely Kanak areas in the northern and Loyalty Islands provinces of New Caledonia. Continuing trouble in the south of Bougainville, and the weak revenue stream of the government still located in the north, have encouraged politicians to consider re-opening the large Panguna copper mine.

New Caledonia's mandatory power-sharing arrangements have so far proved much more successful than similar arrangements in Fiji. In New Caledonia, a 'collegial' executive bringing together pro-independence and loyalist parties has been formed after elections in 1999, 2004 and 2009, although breakdowns have been frequent recently. Fiji's arrangements, which were poorly grafted at the last moment onto a Westminster-based 1997 constitution, proved much less successful. The first government elected under those rules in 1999 successfully excluded the largest ethnic Fijian party (measured by share of the vote), while the second government elected in 2001 excluded the largest Indian backed party from cabinet (and consequently was judged to be in breach of the constitution). 
When a government was finally forged that obeyed the power-sharing rules in May 2006, it was overthrown only seven months later by a military coup. Fiji's arrangements were heavily influenced by the experience in South Africa during the transition from Apartheid. Power-sharing arrangements for deeply divided polities (including South Africa) have been heavily canvassed by University of California political scientist Professor Arend Lijphart (1977): the origins of his 'consociational' model go back to continental European democracies like the Netherlands, Belgium, Switzerland and Austria.

In this chapter I have tried to answer the question of 'how relevant are European models?' largely in the past tense: 'How relevant have European models been?' Almost by definition, European models were highly influential during the colonial era, though Europeans rarely ruled subject peoples as they ruled their own peoples. The post-colonial legacy was mixed; influences were obvious on systems of law and government, but flexibility was greater than often imagined. As the island states enter their third, fourth or fifth decade since independence, that influence has waned further, while other influences have grown. In many ways, the Asian or African history may provide the more useful lessons, even if the Pacific Islands' experience differs markedly also from those regions. Issues of state- and nation-building in the 21 st century are not the same as those faced in the 19th or early 20th centuries, not least as the Melanesian experience clearly shows, due to the impact on state formation of large resource-extractive mining or logging interests.

Nowadays, simple transplantations are usually the least successful. Lifting models of government from one part of the world to another is a hazardous exercise: institutions can operate very differently in different contexts. The problems are different, the issues often unfamiliar and the proposed solutions commonly half-baked. Even amongst the European models of government, the variety is extraordinary, and those from one European country are often unfamiliar with forms of government in another.

Nevertheless, a comparative lens is often useful, but only on the basis of a rich understanding of the specific tensions witnessed within the Pacific region. When Tonga, as it did ahead of the first ever elections to a majority popularly elected parliament in November 2010, considers adopting a single transferable vote system, it helps to know something about the operation of that system in Ireland and Northern Ireland and Malta (even if only to reject that option, as the Tongan government - rightly I believe - did). When Papua New Guinea (or for that matter French Polynesia) struggles with floor-crossing and 'no confidence' votes, it helps to know something about how France dealt with those problems in the 1950s when a strong presidential system was adopted, even if a highly majoritarian presidential system would create major problems in a hyperfractionalised and extremely heterogeneous polity like PNG. 
This is not to urge some rampant exceptionalism or resistance to foreign models. Fiji's coup leader Frank Bainimarama oddly combines a perverse embrace of western models of 'good governance' in his struggle with Fijian traditionalists and a rejection of imported models of democracy as unsuitable. He urges that ethnic cleavages, weak development and corruption are to be resolved by military dictatorship, though we know from the experience in Africa, Latin America and even parts of Europe that this is false, and that such divisions are better handled by strengthening democratic institutions.

Nor are transplantations always failures. The French law on parity, for example, aimed at increased women's representation but has had a restricted impact on mainland France, where elections to the National Assembly use a single member district system. Transplanted to the Pacific territories of New Caledonia and French Polynesia, it has had a major impact because these use a list proportional representation system for elections to territorial assemblies, and because both have well-established party systems. As a result, both New Caledonia and French Polynesia have close to 50 per cent women's representation, uniquely across the Pacific Islands. The story of how local women's organisations and aspiring female politicians handled these exported changes in law has yet to be fully told.

Both models from elsewhere and imported institutions can thus - in unusual circumstances - play significant and positive roles, sometimes in unexpected ways, but in general those urging such reforms or changes would do wisely to avoid grandstanding on international principle, and instead to base arguments on a deep and rich appreciation of the local contexts.

\section{References}

Herbst, J. 2000. States and Power in Africa: Comparative Lessons in Authority and Control. Princeton: Princeton University Press.

Lijphart, A. 1977. Democracy in Plural Societies: a Comparative Exploration. New Haven: Yale University Press.

Samson, J. 1998. Imperial Benevolence: Making British Authority in the Pacific Islands. Honolulu: University of Hawaii Press .

Tilly, C. 1990. Coercion, Capital, and European States, AD 990-1990. Cambridge, Mass.: Blackwell. 